\title{
[Tinjauan Buku] \\ Paradoks Kerja di era Post-Industrial: \\ Antara Fleksibilitas, Ketidakpastian, dan Kepuasan
}

\section{Gendis Syari Widodari, Andeta Karamina}

Youth Studies Centre Fisipol UGM

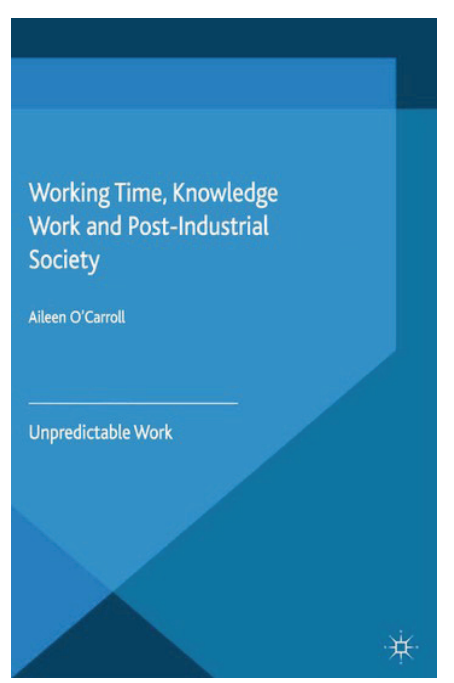

Judul Buku

Pengarang

Penerbit

Tahun

ISBN
: Working Time, Knowledge Work and PostIndustrial Society

: Aileen O'Carroll

: Palgrave Macmillan UK

: 2015

: $978-1-137-31848-0$

\section{PENDAHULUAN}

Working Time, Knowledge Work and Post-Industrial Society adalah buku yang ditulis oleh Aileen O'Carroll mengenai sistem kerja era post-industrial, terutama bagi perusahaanperusahaan software di Irlandia. Buku ini secara garis besar menjelaskan tentang akumulasi dari pengaturan jam kerja, proses bekerja, kultur kolega, dan sistem serta struktur perusahaan yang secara interkonektif menimbulkan ketidakpuasan dari pekerja itu sendiri.

Uraian argumentasi yang dipaparkan di dalam buku dimulai dengan sebuah pernyataan bahwa waktu kerja mempengaruhi banyak aspek dari kehidupan seseorang. Hal ini tidak lepas dari faktor budaya temporal yang diasosiasikan di dalamnya, di mana budaya tersebut dinamis dan berubah mengikuti apa yang dipahami sebagai 'normal' di dalam pembuatan dan distribusi jam kerja. Aileen O’Carroll mengkaji isu ini dengan melakukan analisis aktivitas pekerja yang bergelut di bidang software dalam industri high-tech di Irlandia. Penulis berusaha melihat bagaimana para pekerja beradaptasi dengan ketidakpastian (unpredictability) yang terjadi terhadap waktu kerja, dan kini hadir sebagai salah satu komponen dari budaya kerja masyarakat. Ketidakpastian didefinisikan sebagai variasi waktu awal dan akhir dari keseluruhan waktu bekerja seseorang, yang sengaja dipaksakan oleh proses-proses di dalamnya. Kondisi ketidakpastian mempengaruhi bagaimana waktu dipersepsikan dalam kehidupan sehari-hari, di mana selanjutnya menjadi basis cara berpikir pekerja dalam melakukan rutinitas yang tidak lagi dapat diprediksi berdasarkan 'standar' yang berlaku.

O'Carroll menyampaikan bahwa standar waktu kerja yang masih bertahan di mayoritas 
negara saat ini ditekan untuk berubah menjadi hal yang tidak dapat dipastikan. Hal yang menjadi menarik adalah semakin fleksibel para tenaga kerja yang mendapatkan kesempatan untuk menentukan jam kerja, justru lebih besar kemungkinannya untuk mengalami tekanan (p.10). Dalam uraian di atas, korelasi antara tekanan dan standar kerja serupa dengan apa yang dikatakan Gramsci mengenai contradictory consciousness -yaitu bagaimana kelompok pekerja memiliki dua kesadaran yang kontradiktif akibat dipengaruhi oleh cara pikir hegemonik kelompok dominan (Gramsci 1999). Fenomena ini diperkuat oleh Hochschild di dalam argumennya, bahwa ketiadaan batasan dalam waktu kerja dan privat membuat seseorang lebih tertekan dibandingkan mereka yang memiliki kepastian waktu dalam menjalani aktivitas (Hochschild 1997: 8). Menurut Thompson (1986), sistem kerja per jam saat ini menjadi alat dominan yang membentuk persepsi masyarakat mengenai waktu kerja dan lebih jauh lagi berkenaan dengan konsep waktu secara general. Pendapat mengenai dominasi pemahaman waktu yang dijelaskan oleh Thompson diperkuat melalui korelasi yang ia hubungkan, yaitu hubungan antara peristiwa revolusi industri dan lahirnya ungkapan "waktu adalah uang”, yang hingga kini menjadi cara dominan untuk menggambarkan waktu. Sifat waktu di dalam masyarakat kapitalistik menjadikannya sebagai komoditas yang harus dihabiskan, dipasarkan, dan digunakan (Thompson 1986: 395). Dengan demikian, waktu telah mengalami perubahan fungsi sebagai bagian dari kekuatan material di dalam sistem kapitalisme yang berpihak pada kepentingan kelompok dominan - di mana dalam konteks ini adalah korporasi industri.

Pada bab selanjutnya, buku ini membahas mengenai mitos jam kerja yang terjadi di dalam sektor software di Irlandia. Studi kasus ini tentu menjadi relevan untuk ditunjukkan sebagai referensi dalam melihat kondisi serupa atas peningkatan kerja berbasis komputer terjadi di Indonesia (ILO 2017). Di dalam bukunya, O’Carroll memperlihatkan bagaimana mitos durasi jam kerja di lapangan diselaraskan dengan tingginya penyerapan tenaga kerja muda yang memiliki keterikatan lebih rendah dengan hal eksternal lainnya. Penulis menyediakan data-data yang akurat untuk membuktikan bahwa konsepsi tersebut adalah mitos, di mana jam kerja yang panjang memang bertahan namun tidak menjadi dominan (p. 24). Fleksibilitas waktu yang diberikan kepada pekerja oleh perusahaan, membuat jam kerja di dalam satu Minggu menjadi lebih panjang (Lowe and Oliver 1991) karena framing tambahan waktu kerja yang dikemas sebagai emergency work time. Keberadaan ekspektasi yang diminta oleh perusahaan terhadap karyawannya membuat para pekerja secara kultural memberikan persetujuan untuk bekerja lebih panjang daripada seharusnya.

Argumen O'Carroll relevan dengan konsep contradictory consciousness dan hegemoni kultural Gramsci, bahwa asumsi durasi kerja yang panjang telah menjadi norma -bukti bahwa pemahaman ini adalah cara pikir dominan yang hegemon. Hegemoni kultural yang terbentuk secara tidak sadar bekerja sebagai aturan yang tidak tertulis, sehingga mengakibatkan tekanan bagi pekerja untuk menaatinya dan mencapai taraf hingga waktu diperlakukan sebagai bagian dari kehidupan, dibentuk, dan dihasilakan di level agensi individu (Adam 1995).

Sosiolog Barbara Adam berargumen bahwa waktu mengalami penghitungan, dekontekstualisasi, rasionalisasi, dan terkomodifikasi di dalam tahapan organisasi. Dapat dilihat bahwa komodifikasi waktu ini adalah proses yang terjadi akibat pengaruh dari sistem kapitalisme yang melingkupi pekerja. Pekerjaan software terdiri atas rangkaian tugas, dimana knowledge work seringkali tidak dihitung sebagai bagian di dalamnya. O'Carroll, yang diperkuat dengan argumen Leslie Perlow (1997 p. 82), mendeskripsikan bahwa pekerjaan yang terdiri atas ide dan hasil pikir bagi para insinyur dipandang hanya sebagai gangguan semata. Padahal aspek pemikiran di dalam pekerjaan insinyur 
dan mereka yang bekerja di bidang teknologi, menjadi aspek yang penting untuk membuatnya berhasil (p. 40). Konsepsi dominan kita mengenai pekerjaan IT adalah cara kerja teknologi komputer di dalamnya. Pemikiran atau knowledge work yang dimiliki oleh pekerja merupakan sebuah proses yang tidak pasti dan tidak dapat diduga. Namun, sering kali aspek pikiran manusia yang diperlukan dalam mengembangkan teknologi tersebut tidak diperhitungkan sebagai bagian dari usaha kerja (p. 45). Tentu saja ini menjadi logis karena adanya komodifikasi waktu yang terjadi di dalam sistem. O'Carroll membuktikan argumen ini dengan mengumpulkan studi kasus dari tenaga-tenaga kerja software yang berada di Irlandia, sehingga menjadi kelebihan dari validitas tulisan di dalam bukunya.

Pemaparan yang diberikan O'Carroll dalam membuktikan argumentasinya mengenai ketidakpastian di dalam kultur kerja masyarakat saat ini, disajikan dengan bahasa yang mudah dipahami oleh pembacanya. Selain itu, O'Carroll juga seakan menempatkan pembaca menjadi bagian dari kompleksitas waktu dan ketidakpastian dalam bekerja, sehingga pembaca dapat mencerna pengetahuan dengan logikanya masing-masing. Contohnya, penulis menguraikan poin mengenai kerja multitasking di dalam kerja. Artinya, pekerja memiliki jumlah tugas yang lebih banyak untuk dipertanggungjawabkan.

Buku ini menunjukkan adanya paradoks-paradoks dari fleksibilitas waktu yang dimiliki pekerja. Dimana dalam realitanya fleksibilitas waktu ini tidak memperlihatkan kondisi yang serupa di pekerjaan yang berorientasi terhadap tugas. Knowledge work di dalam konteks ini memiliki aspek ketidakpastian dan terdiri atas dimensi lain yang mana batasan antara pekerjaan dan bukan pekerjaan adalah pori-pori-perbedaan-perbedan kecil di antara keduanya-yang membuat mereka sulit untuk dibedakan. Penulis menunjukkan bagaimana aspek budaya memiliki peran dalam dinamika perubahan di antara keduanya. Hal tersebut mengakibatkan terjadinya konsekuensi sesuai dengan gabungan ketidakpastian, budaya, dan variabel orientasi atas waktu kerja. Hegemoni kultural dalam konteks ini menjelaskan dengan tepat bagaimana budaya tersebut bekerja untuk menekan para pekerja.

Bab kelima dalam buku ini membahas mengenai persetujuan dan proses tawar-menawar yang terjadi antara pekerja dan perusahaan. Proses tawar-menawar ini hadir melalui pergeseran sistem jam kerja konvensional yang tegas ke arah yang lebih cair. Di era pascaindustrial, terutama perusahaan-perusahaan software, jam kerja memang cenderung 'lebih' fleksibel. Perusahaan memberikan jam kerja yang tidak kaku seperti industri manufaktur atau organisasi publik dengan sistem delapan jam kerja. Hal ini juga merupakan respon terhadap kesulitan banyak perempuan pekerja untuk mengikuti jam kerja konvensional sehingga membutuhkan jam kerja yang lebih fleksibel (Hill 2005). Dalam prosesnya, pekerja diberikan otonomi dalam melakukan pekerjaannya.

Buku ini memaparkan bagaimana otonomi di perusahaan software yang diberikan pada kreativitas dan intelektualitas pekerja didasari pada logika how to keep workers interested. Namun, buku ini juga menggambarkan bahwa otonomi yang diberikan memiliki batas-batas tertentu. Hal ini termanifestasikan dalam bentuk sistem batas waktu (deadline). Maka dalam praktiknya, fleksibilitas jam kerja juga cenderung berpotensi menimbulkan kultur jam kerja yang lebih panjang dari biasanya berdasarkan logika 'as long as the job gets done' melalui sistem batas waktu. Putnam, misalnya, menulis mengenai the autonomy paradox dimana pekerja cenderung bekerja lebih lama dan lebih keras ketika diberi fleksibilitas dan kebebasan (Putnam, Myers \& Gailliard 2014).

Melalui bentuk-bentuk praktik di atas, di tataran pekerja sendiri kemudian muncul wujud kolektivitas dan solidaritas antarkolega. Ketika 
proses dan cara menangani suatu tugas atau pekerjaan dikembalikan pada kreativitas dari pekerja, maka muncul kolektivitas dari pekerja untuk bersama-sama menyelesaikan pekerjaan tersebut sesuai dengan batas waktu yang ditentukan. Namun, bab ini juga membahas bagaimana otonomi yang diberikan pada kolektivitas pekerja juga tak jarang berujung pada persoalan kolektif dan hubungan interpersonal antar-kolega.

Bab ini mencontohkan konteks 'masuk jam kerja' yang oleh perusahaan dibebaskan pada pekerja. Namun, kultur yang diciptakan oleh kolega justru menjadi hal yang dibatasi. Misalnya, ketika satu kolega masuk ke kantor pukul 10 pagi sementara kolega lainnya telah berada di kantor sejak pukul 8 pagi, maka muncul perasaan tidak nyaman di antara para pekerja. Jika bab sebelumnya mencoba menganalisis pengaruh struktur terhadap jam kerja, bab lima ini menjelaskan bahwa sistem kerja juga diatur oleh kultur kolektif yang terbentuk di kalangan pekerja. Fenomena kultural di kalangan kolega seperti ini tidak hanya terjadi di Irlandia, tapi juga di banyak negara, termasuk Indonesia. Maka menjadi menarik untuk membaca buku ini lebih jauh untuk memahami bagaimana fenomena ini bekerja.

Di bagian selanjutnya (Bab VI), buku ini membahas bagaimana jam kerja yang panjang menjadi salah satu penyebab dari ketidakpuasan pekerja sehingga pekerja mengambil langkah-langkah tertentu untuk merespon ketidakpuasannya. Dalam bagian ini dijelaskan bahwa ketidakpuasan pekerja biasanya dapat menempuh tiga tahap, pindah atau keluar, penguatan loyalitas terhadap perusahaan, dan protes terhadap sistem perusahaan.

Bab ini sendiri fokus ke proses 'pindah' atau mobilitas pekerja. Bab ini mencoba menarik hubungan antara tren mobilitas tersebut dengan logika kapitalisme Neoliberal yang menempatkan pekerja juga sebagai ‘konsumen' dari tempat kerja -'membebaskan' pekerja untuk 'kerja di tempat lain' jika tidak puas dengan sistem kerjanya saat ini. Buku ini memaparkan ilustrasi mobilitas pekerja di karir-karir organisasional yang cenderung vertikal di organisasi yang sama-dikenal dengan sistem naik pangkat. Namun di era pos-industrial, mobilitas pekerja cenderung berpindah dari satu perusahaan ke perusahaan lainnya akibat ketidakpuasan pekerja. Ketika logika kebebasan mobilitas pekerja dikaitkan dengan narasi constrained autonomy, bab dalam buku ini menjelaskan kecenderungan munculnya diskontinuitas pekerjaan. Implikasinya adalah rencana jangka panjang pekerjaan bertabrakan dengan langkah-langkah yang bahkan tidak direncanakan sebelumnya. Sehingga, arah dan tujuan karir pekerja menjadi sulit diprediksi.

Beberapa bagian terakhir dari buku ini sejatinya mencoba menjawab pertanyaan yang sebenarnya sederhana, "Mengapa pekerja yang memiliki kontrol atas tugas dan jam kerjanya merasa tidak puas dengan kehidupan bekerjanya?" Buku ini mengupas beberapa faktor penyebab ketidakpuasan bekerja akibat tidak adanya keseimbangan-life balance. Di sisi lain, tanggung jawab pekerja dalam mengerjakan tugas-tugasnya - melalui narasi otonomi kreativitas dan intelektualitas-berimplikasi pada jam kerja yang begitu panjang dan bertendensi memunculkan ketidakpuasan.

Buku ini semakin menarik untuk dibaca ketika kita menggunakan perspektif youth dalam melihat fenomena kerja di era Post-industrial. Sulit membicarakan youth dan era Post-industrial sebagai dua hal yang tidak saling berhubungan. Gunter dan Moore, misalnya, mengatakan bawa youth merupakan produk dari masyarakat Post-industrial, dengan karakteristik dependensinya terhadap teknologi (Gunter \& Moore 1975). O'Carroll sendiri dalam buku ini mengatakan bahwa sektor software merupakan 'sektor anak muda', didukung dengan angka pekerja software usia 25-44 yang begitu tinggi di Irlandia. Anak muda merupakan salah satu kelompok masyarakat yang paling terdampak dari transformasi ekonomi Post-industrial 
(Resnick \& Perret-Clermont 2004). Anak muda tidak hanya harus melampaui apa yang disebut Resnick dan Perret-Clermont sebagai 'dependensi terhadap orang lain' menuju 'tanggung jawab kesejahteraan, anak muda juga harus beradaptasi dengan sistem kerja post-industrial yang telah dikupas oleh O'Carroll, yaitu jam kerja fluktuatif, otonomi terbatas, ketidakseimbangan, sistem deadline yang tegas, mobilitas pekerja, dan tentunya kepuasan-atau ketidakpuasan.

\section{DAFTAR PUSTAKA}

Adam, Barbara. 1995. Timewatch: The Social Analysis of Time. Ofxord: Blackwell.

Gunter, B. G. and Harvey A. Moore. 1975. "Youth, Leisure, and Post-Industrial Society: Implications for the Family." The Family Coordinator 24(2):199.

Hill, E. Jeffrey. 2005. "Work-Family Facilitation and Conflict, Working Fathers And Mothers, Work-Family Stressors And Support.” Journal of Family Issues 26(6):793819.

Hochschild, Arlie R. 1997. The Time Bind, When Work Becomes Home and Home Becomes Work. New York: Metropolitan Books.

Lowe, Jim and Nick Oliver. 1991. "The high commitment workplace: Two cases from a hi-tech industry.” Work, Employment, \& Society. London: Sage Publications.

Perlow, Leslie. 1997. Finding Time: How Corporations, Individuals, and Families Can Benefit from New York Practices. Cornell: Cornell University Press.

Putnam, Linda L, Karen K Myers, and Bernadette M Gailliard. 2013. "Examining The Tensions In Workplace Flexibility And Exploring Options For New Directions." Human Relations 67(4):413-440.

Resnick, Lauren B. and Anne-Nelly Perret-Clermont. n.d. "Prospects for Youth in Postindustrial Societies." Joining Society 11-25

Thompson, Edward P. 1968. The Making of the English Working Class. London: Iica.

Thompson, Edward P. 1986. The Social Goals of Agriculture. London: Penguin. 